\title{
Influence of Different Chemical Fungicides against Rice Brown Leaf Spot Disease Caused by Bipolaris oryzae
}

\author{
Nabin Sharma Poudel ${ }^{1 *}$, Prakash Bharatee $^{2}$ and Milan Acharya ${ }^{3}$ \\ ${ }^{1}$ Department of Plant Pathology, Agriculture and Forestry University, Rampur, \\ Chitwan, Nepal \\ ${ }^{2}$ Department of Entomology, Agriculture and Forestry University, Rampur, Chitwan, Nepal, \\ ${ }^{3}$ Ministry of Agriculture and Livestock Development, Nepal \\ *Corresponding author
}

A B S T R A C T

Keywords

AUDPC, Bipolaris,

Economic yield,

Propaconazole,

Rice

Article Info

Accepted:

04 December 2018

Available Online:

10 January 2019
Brown leaf spot of Rice, caused by Bipolaris oryzae $L$ is one of the major rice diseases occurring in World and Nepal. A field experiment to evaluate the efficacy of different chemical fungicides against brown leaf spot of rice was conducted at the farmer's field in Galkot municipality ward no.4. The six different fungicides that were compared with control treatment were Propaconazole, Hexaconazole, Teuboconazole, Carbendazim, Mancozeb allocated in Randomized Completely Block Design (RCBD) and replicated for three times. Application of propiconazole showed the lower AUDPC value (415.7) and highest grain yield (4.277 t/ha) followed by Kyoto (464.3) and SAAF (513.7) as compared to control. From this result, it was concluded that propiconazole can be used to reduce the disease severity and for higher economic yield.

\section{Introduction}

Rice (Oryza sativa) is one of the most important cereal crops of Nepal (Karki et al., 2018 ). Rice covers $15,52,469$ ha of total cultivated land, with the production of 52 , $30,327 \mathrm{mt}$. and the productivity of $3.37 \mathrm{t} \mathrm{ha}^{-1}$ in Nepal (MoAD, 2073/74).

Brown spot, a devastating disease, caused by Bipolaris oryzae $L$. is the most important biotic constraint of rice production occurring in almost all the rice growing land in the
World. The fungal diseases of rice reduce the yield drastically causing significant loss as resulted in the Bengal famine in 1942, when approximately two million people died from starvation (Agrios, 2005). The pathogen after infection shows the symptoms on the leaves, panicles, glumes, and grain causing first as small, circular, and dark brown to purplebrown spots and fully developed lesions are circular to oval with a light brown to gray center, surrounded by a reddish-brown margin and ultimately killing the leaf (Manandhar et al., 2016). 
Temperature, relative humidity and amount of rainfall during the crop season influence the development (Dhaliwal, 2018). The management of the brown spot can be done mainly through resistant varieties, chemicals, biological, cultural, etc. Disease control by foliar spray with bio-agents is not enough for management of disease. Application of fungicides for the control of brown spot is the most effective management option effective and widely recommended methods of disease control (Biswas et al., 2008). Fungicides, such as iprodione, propiconazole, azoxystrobin, and carbendazim are effective in management of brown spot disease (Mandal and Jha, 2008). The objective of the study was mainly focused on identifying the efficacy of different chemical fungicides and suggests the farmers of mid-hill effective fungicide to check the Brown spot disease.

\section{Materials and Methods}

The experiment was carried out at Farmer's field in Galkot Municipality ward no. 3 from July 2 to November 24, 2018. The site is located about $45 \mathrm{~km}$ south-west from Headquarter of Baglung district, Nepal. The experimental site lies at an altitude of 1216 masl, between $28^{\circ} 12^{\prime} 57^{\prime \prime} \mathrm{N}$ latitude and $83^{\circ}$ 25 ' E longitude.

\section{Field Layout}

The experiment was conducted in completely Randomized Block design (RCBD) consisting of 7 treatments (Table 1) with 3 replication for each treatment. Each replication was separated by $1 \mathrm{~m}$ alley and the space between the each treatment was $0.5 \mathrm{~m}$. Each individual plot size was $2 \mathrm{~m}^{2}$ and the net cultivated area was 42 $\mathrm{m}^{2}$. The row to row and plant to plant distances was maintained as $20 \mathrm{~cm} \times 20 \mathrm{~cm}$ such that 10 plants were maintained in each row and total 100 plants in each plot.

\section{Field preparation and transplanting}

Rice variety named as Khumal 9, a long duration variety, was selected for the experiment. Seedlings were raised on the same field of local farmer. Line sowing was practiced for the seedling raising. The main filed was thoroughly ploughed, leveled and puddled. Experimental set up was done. The light irrigation was provided to the seedlings before transplanting. The 21 days old seedlings were transplanted on main filed according to the experimental design. At the time of land preparation, FYM @ 5 ton/ha and half dose of Nitrogen $(\mathrm{N})$ and full doses of Phosphorus (P) and Potassium (K) with the recommended doses of 120:60:40 NPK/ha were applied. Top dressing of remaining half doses of $\mathrm{N}$, irrigation, weeding and hoeing was done as per the requirement.

\section{Application of treatments}

The fungicides were sprayed after each disease scoring on the same day at noon as per the respective treatments with the help of Hand Sprayer.

\section{Disease assessment}

\section{Disease identification}

Disease identification was done by visual method at the experimental site and microscopic confirmation was done at the Plant Pathology Laboratory, Agriculture and Forestry University by examining the infected leaves under compound microscope.

\section{Disease scoring}

Disease scoring was started in the field just after the appearance of the brown spot symptoms in the plot and done. Total five scoring were done in the naturally infested block at the interval of 7 days. First scoring 
was done at 85 DAT followed by 92, 99, 106 and 114 DAT respectively. Disease scoring was assessed visually as foliage damage percent in all the observations using 0-9 scale (Manandhar et al., 2016).

$0=\quad$ No disease on plant

$1=\quad$ Less than $1 \%$ leaf area infected

$2=1-3 \%$ of leaf area infected

$3=4-5 \%$ of leaf area infected

$4=6-10 \%$ of leaf area infected

$5=11-15 \%$ of leaf area infected

$6=16-25 \%$ of leaf area infected

$7=26-50 \%$ of leaf area infected

$8=51-75 \%$ of leaf area infected

$9=\quad$ More than $76 \%$ of leaf area infected

\section{Area under disease progress curve (AUDPC)}

The area under disease progress curve (AUDPC) is used to summarize the progress of disease severity. The AUDPC was estimated using the following formula (Campbell and Madden, 1990).

AUDPC $=\sum_{\mathrm{i}=1}^{\mathrm{n}-1}\left(\mathrm{Y}_{\mathrm{i}+1}+\mathrm{Y}_{\mathrm{i}}\right) 0.5\left(\mathrm{~T}_{\mathrm{i}+1}-\mathrm{T}_{\mathrm{i}}\right)$

Where

$Y_{i}=$ late blight disease severity $\%$ on the $i^{\text {th }}$ date

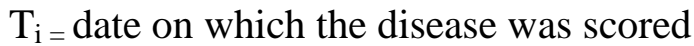

$\mathrm{n}=$ numbers of dates on which disease was scored

\section{Statistical analysis}

The entry of recorded data was done using MS-excel 2007 program. The data were processed to fit into GenStat Fifteenth edition Version 15.1.0.8035 software for analysis. DMRT was done at 5\% level of significance for mean comparison.

\section{Results and Discussion}

The seven different chemical fungicides were tested against the brown spot disease of the rice. The Area Under disease progressive curve (AUDPC) value was calculated on the basis of the disease severity recorded in different dates 85 DAT, 92 DAT, 99DAT, 106 DAT and 113 DAT (Table 2). Significantly lowest AUDPC value was observed in the field treated with the Propicanazole (415.7) which was statistically par with Azoxystrobin + Tebuconazole. (464.3) and followed by Carbendazim+ Mancozeb (464.3). The plot with control treatment showed the maximum AUDPC value (723.4). Gupta et al., 2013 found the reduction of disease severity with the application of Propicanazole to $08.24 \%$.

The disease severity of brown spot was insignificant difference among the treatments during first two scoring D85and D92. But third, fourth and fifth disease severity scoring showed the significant different among the treatments. The application of propicaonazole significantly reduced the disease severity followed by Kyoto, SAAF, Hexaconazole, Carbendazim and Mancozeb.

\section{Test weight and grain yield}

Maximum test weight (12.68) and grain yield (4.277 t/ha) was obtained from propiconazole followed by Azoxystrobin + Tebuconazole (12.62) and (4.120 t/ha) respectively. So, Propiconazole and Tebuconazole + Azoxystrobin appeared as the efficient ones against brown leaf spot among all chemical fungicides in the field (Table 3). The application of SAAF, Hexaconazole, Cabendazim and Mancozeb resulted in average grain yield of $3.847 \mathrm{t} / \mathrm{ha}, 3.377 \mathrm{t} / \mathrm{ha}$, $3.470 \mathrm{t} / \mathrm{ha}$ and $3.333 \mathrm{t} / \mathrm{ha}$ respectively as compared to control $(2.793 \mathrm{t} / \mathrm{ha})$. 
Table.1 Treatments of experiment with notations

\begin{tabular}{|l|l|l|}
\hline Trade Name & Generic Name & Notations \\
\hline Built & Propicanazole 25\% EC & T1 \\
\hline Bavistin & Carbendazim 50\% WP & T2 \\
\hline Dithan M-45 & Mancozeb 75\% WP & T3 \\
\hline Cryzol & Hexaconazole 5\% SC & T4 \\
\hline SAAF & Carbendazim 63\% + Mancozeb 12\% WP & T5 \\
\hline Kyoto & Azoxystrobin 11\% + Tebuconazole 18.30\% SC & T6 \\
\hline & Control & T7 \\
\hline
\end{tabular}

Table.2 Mean disease severity value of rice at different DAT treated with different chemical fungicides in field at Baglung, Nepal

\begin{tabular}{|c|c|c|c|c|c|}
\hline Treatments & D85 & D92 & D99 & D106 & D113 \\
\hline Propicanazole & $8.72^{\mathrm{ab}}$ & $12.76^{\mathrm{a}}$ & $16.96^{\mathrm{a}}$ & $16.70^{\mathrm{a}}$ & $12.99^{\mathrm{a}}$ \\
\hline Carbendazim & $10.23^{\mathrm{ab}}$ & $16.88^{\mathrm{ab}}$ & $20.35^{\mathrm{b}}$ & $21.79^{\mathrm{bc}}$ & $22.26^{\mathrm{cd}}$ \\
\hline Mancozeb & $9.43^{\mathrm{ab}}$ & $16.02^{\mathrm{ab}}$ & $19.68^{\mathrm{b}}$ & $23.30^{\mathrm{c}}$ & $24.35^{\mathrm{d}}$ \\
\hline Hexaconazole & $10.39^{\mathrm{ab}}$ & $15.30^{\mathrm{ab}}$ & $22.00^{\mathrm{b}}$ & $20.71^{\mathrm{abc}}$ & $19.13^{\mathrm{bc}}$ \\
\hline Carbendazim + Mancozeb & $9.13^{\mathrm{ab}}$ & $14.85^{\mathrm{ab}}$ & $21.68^{b}$ & $20.20^{\mathrm{abc}}$ & $17.36^{\mathrm{b}}$ \\
\hline Azoxystrobin + Tebuconazole & $7.613^{\mathrm{a}}$ & $15.96^{\mathrm{ab}}$ & $20.25^{\mathrm{ab}}$ & $18.30^{\mathrm{ab}}$ & $15.74^{\mathrm{ab}}$ \\
\hline Control & $11.68^{\mathrm{b}}$ & $19.40^{\mathrm{b}}$ & $25.11^{\mathrm{c}}$ & $30.94^{\mathrm{d}}$ & $38,39^{\mathrm{e}}$ \\
\hline Mean & 9.600 & 15.74 & 20.72 & 21.71 & 21.41 \\
\hline F value & NS & NS & * & ** & ** \\
\hline $\operatorname{SeM}( \pm)$ & 1.350 & 2.036 & 1. 166 & 1.912 & 1.605 \\
\hline LSD (0.05) & 2.941 & 4.436 & 2.541 & 4.166 & 3.497 \\
\hline CV $(\%)$ & 17.2 & 15.8 & 6.9 & 10.8 & 9.2 \\
\hline
\end{tabular}

Table.3 AUDPC value, test weight and grain yield of rice treated with different chemical fungicides in field at Baglung, Nepal

\begin{tabular}{|c|c|c|c|}
\hline Treatments & AUDPC Value & Test weight & Grain Yield \\
\hline Propiconazole & $415.7^{\mathrm{a}}$ & $12.68^{\mathrm{c}}$ & $4.277^{\mathrm{c}}$ \\
\hline Carbendazim & $539.0^{c}$ & $12.00^{\mathrm{bc}}$ & $3.333^{\mathrm{ab}}$ \\
\hline Mancozeb & $544.1^{\mathrm{c}}$ & $10.23^{\mathrm{a}}$ & $3.377^{\mathrm{ab}}$ \\
\hline Hexaconazole & $532.9^{\mathrm{c}}$ & $12.04^{b c}$ & $3.470^{\mathrm{abc}}$ \\
\hline Carbendazim + Mancozeb & $513.7^{\mathrm{bc}}$ & $12.35^{\mathrm{c}}$ & $3.847^{\mathrm{bc}}$ \\
\hline Azoxystobin + Tebuconazole & $464.3^{\mathrm{ab}}$ & $12.62^{\mathrm{bc}}$ & $4.120^{\mathrm{bc}}$ \\
\hline Control & $723.4^{\mathrm{d}}$ & $11.13^{\mathrm{ab}}$ & $2.793^{\mathrm{a}}$ \\
\hline Mean & 533.3 & 11.87 & 3.602 \\
\hline F value & ** & * & * \\
\hline $\operatorname{SEM}( \pm)$ & 28.90 & 0.616 & 0.3653 \\
\hline LSD(0.05) & 62.97 & 1.342 & 0.7959 \\
\hline $\operatorname{Cv}(\%)$ & 6.6 & 6.4 & 12.4 \\
\hline
\end{tabular}


Figure.1 Relationship between AUDPC value and economic yield of rice treated with different chemical fungicides in field at Baglung, Nepal

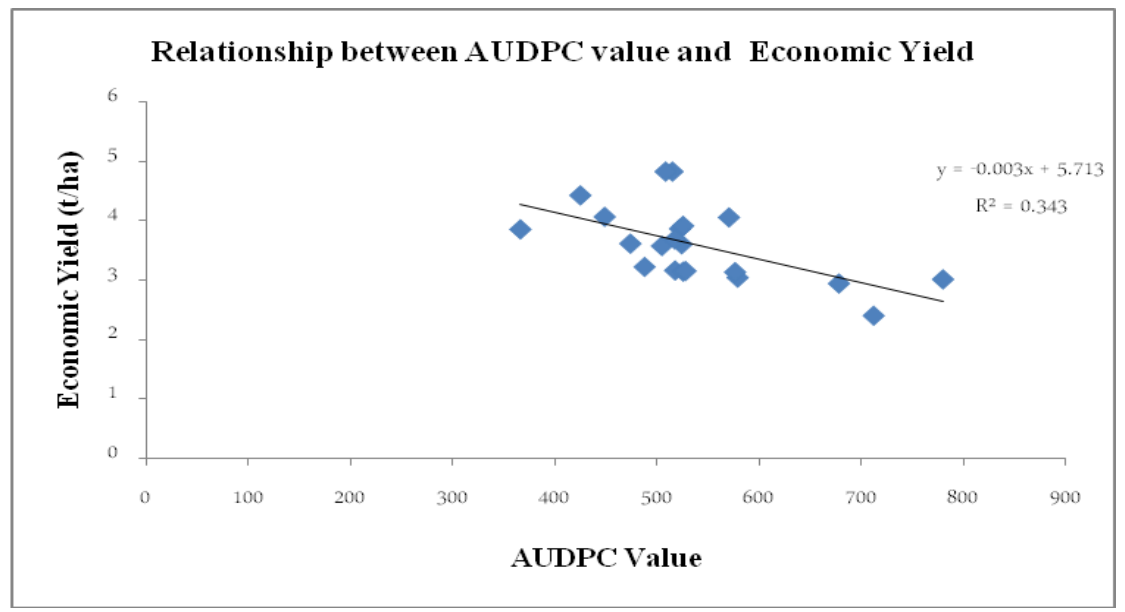

Figure.2 Relationship between AUDPC Value and test weight of rice treated with different chemical fungicides in field at Baglung, Nepal

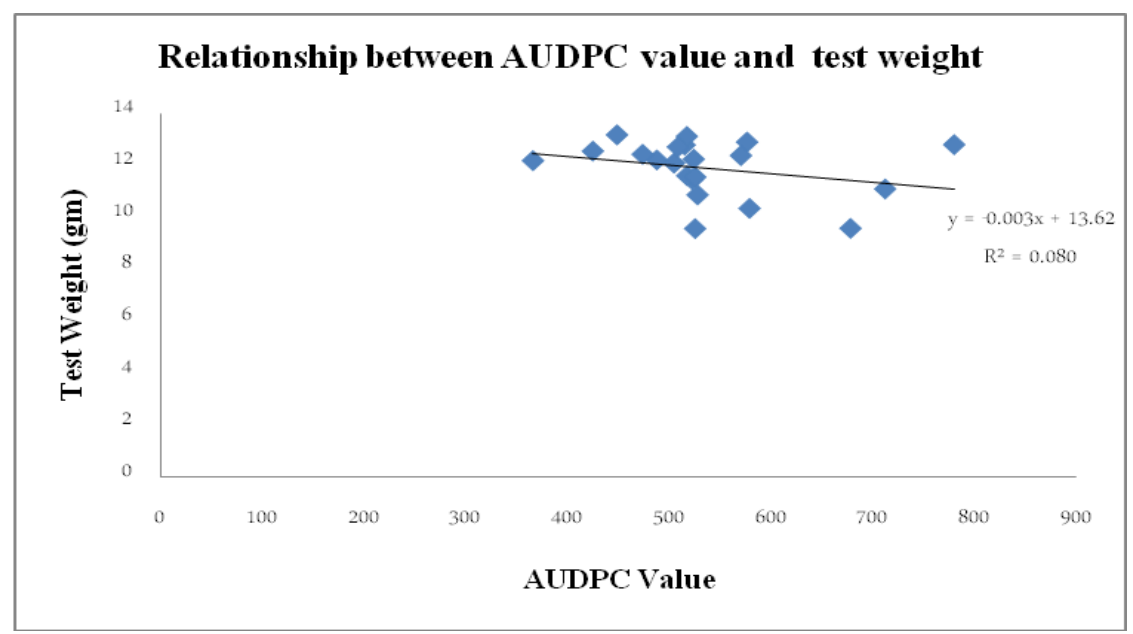

\section{Correlation and regression analysis}

There was significant negative correlation between AUDPC Value and grain yield $\left(\mathrm{R}^{2}=\right.$ $0.343)$ and test weight $\left(\mathrm{R}^{2}=0.080\right)$ (Figure 1). The AUDPC Value contributes approximately $34.3 \%$ variation in the grain yield and remaining $65.7 \%$ variation due to variables other than AUDPC. Similarly about $8 \%$ variation in test weight of grains was due to AUDPC value (Figure 2) and remaining portion due to other factors. According to the linear equation, per unit increase in AUDPC value, test weight decreased by 0.003 times.

In conclusion the efficacy evaluation of different chemical fungicides available in the market against brown leaf spot disease of rice showed that application of propiconazole for management of brown spot in field was most effective in both reducing the diseases severity and economic yield than other tested fungicides. So, propiconazole was recommended for the farmers. 


\section{References}

Agrios, G. N., 2005. Plant Pathology. Elsevier Academic Press. pp. 468-469.

Biswas, S.K., Ratan, V., Srivasta, S. and Singh, R., 2008. Influence of seed treatment with biocides and foliar spray with fungicides for management of brown leaf spot and sheath blight of paddy. Indian Phytopathology, 61(1): 55-59.

Dhaliwal, L.K., Sandhu, S.K., Kaur, S. and Singh, S., 2018. Effect of meteorological parameters on incidence of brown leaf spot in rice crop under different planting methods. Journal of Agrometeorology 20 (1): 53-56

Gupta, V., Shamas, N., Razdan, V.K., Sharma, B.C., Sharma, R., Kaur, K., Singh, I., John, D. and Kumar, A., 2013. Foliar application of fungicides for the management of brown spot disease in rice (Oryza sativa L.) caused by Bipolaris oryzae. African Journal of Agricultural Research, 8(25), pp.3303-3309.

Harish, S., Saravanakumar, D., Radjacommare, R., Ebenezar, E.G. and Seetharaman, K., 2008. Use of plant extracts and biocontrol agents for the management of brown spot disease in rice. BioControl, 53(3), p.555.

Karki, S., Poudel, N.S., Bhusal, G., Simkhada, S., Regmi, B. R., Adhikari, B. and Poudel, S. 2018. "Growth Parameter and Yield Attributes of Rice (Oryza sativa) as Influenced by Different Combination of Nitrogen Sources." World Journal of Agricultural Research, vol. 6, no. 2: 58-64. doi: 10.12691/wjar-6-2-4.

Manandhar, H.K.., Timila R.D., Sharma, S., Joshi, S., Manandhar, S. Gurung, S.B., Sthapit, S., Palikhey, E., Pandey, A., B.K., Joshi, Manandhar, G., Gauchan, D., Jarvis D.I. and Sthapit, B.R., 2016. A field guide for identification and scoring methods of diseases in the mountain crops of Nepal. Bioversiy International, Pp. 138-138.

Mandal, S. K. and V. B. Jha. 2008. Management of foliar disease of rice through fungicides. Ann. Plant Protection Science 16: 523-25.

MoAD. 2073/74. Statistical information on Nepalese agriculture. Government of Nepal. Ministry of Agricultural Development. Agribusiness Promotion and Statistics Division, Singha Durbar, Kathmandu, Nepal.

\section{How to cite this article:}

Nabin Sharma Poudel, Prakash Bharatee and Milan Acharya. 2019. Influence of Different Chemical Fungicides against Rice Brown Leaf Spot Disease Caused by Bipolaris oryzae. Int.J.Curr.Microbiol.App.Sci. 8(01): 441-446. doi: https://doi.org/10.20546/ijcmas.2019.801.046 